\title{
High in vitro Shoot Multiplication for Efficient Micropropagation of Banana Cv. Robusta (AAA)
}

\author{
Anita Kumari* and Harsh Kumar
}

Department of Agricultural Biotechnology and Molecular Biology, Dr. Rajendra Prasad Central Agricultural University, Pusa, Bihar, India- 848125

*Corresponding author

\begin{abstract}
A B S T R A C T
Keywords

Banana, Robusta, Shoot apices, Micropropagation, Subculture cycle and Multiple shoot formation

Article Info

Accepted:

24 June 2018

Available Online:

10 July 2018

The cultivar Robusta forms the mainstay of commercial banana cultivation in India. An efficient micropropagation system with high multiplication rate will boost banana cultivation and assist banana based industries in the country. The shoot apices of banana cv. Robusta were cultured on two basal media MS and B5 supplemented with different concentrations and combinations of plant growth regulators (PGR). The tissue culture responses were observed for shoot multiplication and effect of subculture on rate of shoot multiplication till $8^{\text {th }}$ subculture. The maximum frequency of multiple shoot formation $(97.95 \%)$ and number of differentiated shoots per culture (27.25) was achieved on medium M11 (MS+1.14 $\mu \mathrm{M}$ IAA+19.97 $\mu \mathrm{M}$ BAP). The medium was further used for the multiplication of shoot buds upto eight subculture cycles. The mean number of differentiated shoots per culture was maintained upto $5^{\text {th }}$ subculture cycle thereafter declined in $6^{\text {th }}(-16.67 \%)$ to $8^{\text {th }}(-40.35 \%)$ subcultures. The in vitro developed shoots were rooted on medium M17 (MS + $4.92 \mu \mathrm{M}$ IBA). The well rooted plantlets were acclimatized to field condition.
\end{abstract}

\section{Introduction}

Robusta (AAA) is one of the most important commercial cultivar of banana grown in AsiaPacific. It is a clone of the dominant Dwarf Cavendish cultivar and covers majority of the area under cultivation of banana in India because of many superior features such as pleasantly flavoured, attractive colour, pulpy fruits, exportable large bunches and robust pseudostem which can withstand strong winds (Ghosh et al., 2009). It is popular with other names as Poya, Valery or Tall Mons Mari in other countries (Simmonds, 1982). Robusta is the main cultivar grown in Koshi region of Bihar.

Cultivar Robusta is conventionally propagated through suckers with low multiplication rate. The propagules carry pest and pathogen and the resultant plants require longer period for flowering and fruiting. Micropropagation helps in overcoming the problems of conventional propagation and allows regeneration of large population of disease free quality plants in a short period of time for 
planting in new areas. Further, micropropagated plants are healthier, early maturing and bear longer bunch with larger fruits in higher numbers.

There is lack of a proficient micropropagation system utilizing shoot apices in the cv. Robusta. There are few reports with low multiplication rates (Vani and Reddy, 1999; Senthilkumar and Ramsundar, 2009; Choudhary et al., 2014). Thus, the objective of the work is to develop an efficient dexterous microproapagtion system for $\mathrm{cv}$. Robusta to enhance production of quality propagules with less time and effort.

\section{Materials and Methods}

Collection of disease free healthy sword suckers of banana cv. Robusta was done from the experimental field of the Department of Horticulture, Dr. Rajendra Prasad Central Agricultural University, Pusa, Bihar, India. The collected explants were then prepared and pretreated as suggested by Kumari and Kumar (2016). The prepared explants were brought to laminar air flow after washing with distilled water. A solution of $0.2 \% \mathrm{HgCl}_{2}$ was applied to the explants for their surface sterilization. The traces of $\mathrm{HgCl}_{2}$ solution was removed by three consecutive washing of the explants with sterile distilled water.

The prepared explants were further trimmed to a size of $0.5 \mathrm{~cm}^{3}$ cube containing apical meristem and inoculated individually onto the selected medium, which consisted of MS and B5 basal media supplemented with different concentrations and combinations of plant growth regulators (Auxins- 2,4-D, IAA and IBA; and Cytokinins- BAP, KIN and TDZ) (Table 1) (Figure 1A). The cultures were incubated in culture room at an ambient temperature of $25 \pm 2{ }^{\circ} \mathrm{C}$, with continuous fluorescent light of about 2 kilo lux intensity and relative humidity (RH) 50 to $80 \%$.
The differentiated multiple shoots were routinely subcultured after $6^{\text {th }}$ week for further proliferation, multiplication and maintenance. They were divided into groups of 3-5 shoots and inoculated into individual culture bottles. After sufficient propagule multiplication, preferably in sixth subculture, the proliferated healthier differentiated shoots were further divided into single shoots and inoculated into rooting medium for development of roots to acquire a complete plantlet. The well developed tissue cultured plantlets having healthy shoot and roots were selected for acclimatization. The banana plantlets were removed cautiously from culture bottles. The adhered medium from the roots of the plantlets were gently removed by washing with a soft brush and transferred to a mixture of sterilized sand and compost (1:1) individually in plastic pots. The plantlets were initially kept under high humid conditions in an acclimatization chamber for primary acclimatization in progressive way for 30 days. The primary acclimatized plantlets of banana were then transferred to green house for secondary acclimatization. Acclimatized banana plantlets were subsequently transferred to field.

The in vitro responses were observed and recorded at progressive stages. The experiments were set up in a completely randomized design (CRD) with a minimum of 30 cultures per treatment. All the data were analyzed in CRD by executing one factor analysis of variance (ANOVA) using OP Stat. The means were compared using Duncan's multiple range test (Duncan, 1955) to find the difference at $5 \%(\mathrm{P}<0.05)$ level. The results were expressed as mean $\pm \mathrm{SE}$ of four replications.

\section{Results and Discussion}

The multiple shoot differentiation from the cultured shoot apices of banana cv. Robusta 
was observed after twenty to thirty days of culture. New multiple shoot buds were observed proliferating form the basal margin of the cultured explant (Figure 1B). The extent of shoot multiplication was evaluated on the basis of the frequency and the number of differentiated shoots per culture. The frequency of multiple shoot formation ranged from 26.43 to $97.95 \%$ and the number of differentiated shoots per culture from 7.25 to 27.25. The best multiple shoot formation of 97.95\% was observed on the medium M11 $(\mathrm{MS}+1.14 \mu \mathrm{M}$ IAA+19.97 $\mu \mathrm{M}$ BAP) which was at par to $95.71 \%$ on medium M14 (B5 + $1.14 \mu \mathrm{M}$ IAA $+19.97 \mu \mathrm{M}$ BAP). The medium M4 (MS + 22.19 $\mu \mathrm{M}$ BAP) showed the next best frequency of shoot proliferation (93.59\%). The culture on medium M11 resulted in the highest number of differentiated shoots per culture (27.25) which was at par to medium M14 (25.50) and closely followed by medium M4 (23.25). The other media M3 (MS + $17.75 \mu \mathrm{M}$ BAP) and M5 (MS + $23.23 \mu \mathrm{M}$ KIN) also resulted in good multiple shoot formation (Table 1). Whereas, the media M6 (MS + $4.54 \mu \mathrm{M}$ TDZ) and M7 (MS + 9.08 $\mu \mathrm{M}$ TDZ) were at par for the induction of low shoot multiplication.

The multiplied shoots on medium M11 were further subcultured to increase the total number of in vitro developed shoots onto the same medium (Figure 1C). The multiple shoot formation frequency from subcultured in vitro develop shoots was not affected by the number of culture cycles generally and remained cent-percent. However, number of differentiated multiple shoots per subculture varied with the increasing culture cycles. The mean number of differentiated shoots per culture was at par till $3^{\text {rd }}$ subculture. Furthermore, it remained more or less same upto $5^{\text {th }}$ subculture cycle. The potential of subcultured propagule multiplication in terms of number of differentiated shoots per culture declined by $16.67 \%$ in $6^{\text {th }}$ subculture, $28.07 \%$ in $7^{\text {th }}$ subculture and $40.35 \%$ in $8^{\text {th }}$ subculture
(Table 2). The differentiated multiple shoots were divided into single shoots and subcultured for the proper development of roots on the medium $\mathrm{MS}+4.92 \mu \mathrm{M}$ IBA following the work of Kumari and Kumar (2016) (Figure 1D). The observed root formation from in vitro developed plantlets was cent-percent on this medium.

The tissue culture derived plantlets of banana cv. Robusta comprising well developed roots and healthy shoot were acclimatized progressively to natural environment was apposite in term of establishment to field conditions, plant growth and morphology in contrast to ex vitro developed parent plant (Figures $1 \mathrm{E}, \mathrm{F}$ ).

Shoot apices although are not readily available explants due to less sprouting of suckers from the base of banana in ex vitro conditions, but they are the best explants to acquire multiple propagules with less variations in in vitro conditions. Multiple shoot formation was supported by the media having moderate to high concentrations of only cytokinin and low auxin with high cytokinin. The best multiple shoot formation and the highest number of differentiated shoots was observed on medium M11, which was at par to medium M14. Both of the media are constituted with low concentrations of auxin IAA and high concentrations of cytokinin BAP. The classical hypothesis of 'chemical control of organogenesis' suggested that low concentrations of auxin with high concentrations of cytokinin supported multiple shoot formation (Skoog and Miller, 1957). The concentration of auxin in cells determines the position of quiescent centre (Jiang et al., 2003). The threshold concentration of auxin in the nucleus resulted in degradation of AUX/IAA a transcriptional repressor and subsequent activation of transcription of auxin biosynthesis pathway by dimerization of ARFs (Auxin response factors) proteins (Taiz and Zeiger, 2010). 
Table.1 The effect of different media on percentage multiple shoot formation and number of differentiated shoots per cultured shoot apex of banana cv. Robusta

\begin{tabular}{|c|c|c|c|c|}
\hline S. No. & $\begin{array}{l}\text { Media } \\
\text { Name }\end{array}$ & Media Compositions & $\begin{array}{l}\text { Multiple shoot formation } \\
\quad \%(\text { mean } \pm \text { SE) }\end{array}$ & $\begin{array}{c}\text { No. of } \\
\text { shoot/explants }\end{array}$ \\
\hline 1 & M1 & $\mathrm{MS}+4.44 \mu \mathrm{M} \mathrm{BAP}$ & $62.02^{\mathrm{e}} \pm 1.52$ & $14.00^{\mathrm{cd}} \pm 0.41$ \\
\hline 2 & M2 & $\mathrm{MS}+8.88 \mu \mathrm{M}$ BAP & $63.04^{\mathrm{e}} \pm 1.34$ & $16.50^{\mathrm{bc}} \pm 0.50$ \\
\hline 3 & M3 & $\mathrm{MS}+17.75 \mu \mathrm{M}$ BAP & $72.46^{c} \pm 0.67$ & $17.25^{b} \pm 0.85$ \\
\hline 4 & M4 & $\mathrm{MS}+22.19 \mu \mathrm{M}$ BAP & $93.59^{b} \pm 1.44$ & $23.25 \pm 0.48$ \\
\hline 5 & M5 & $\mathrm{MS}+23.23 \mu \mathrm{M} \mathrm{KIN}$ & $71.28^{\mathrm{cd}} \pm 0.67$ & $16.50^{\mathrm{bc}} \pm 0.64$ \\
\hline 6 & M6 & $\mathrm{MS}+4.54 \mu \mathrm{M} \mathrm{TDZ}$ & $26.43 \pm 1.83$ & $7.25^{\mathrm{f}} \pm 0.48$ \\
\hline 7 & M7 & $\mathrm{MS}+9.08 \mu \mathrm{M} \mathrm{TDZ}$ & $33.88 \pm 0.94$ & $8.25^{\mathrm{f}} \pm 0.48$ \\
\hline 8 & M8 & $\mathrm{MS}+9.05 \mu \mathrm{M} 2,4-\mathrm{D}+19.97 \mu \mathrm{M}$ BAP & $42.29^{f} \pm 0.84$ & $12.00^{\mathrm{d}} \pm 0.91$ \\
\hline 9 & M9 & $\mathrm{MS}+9.05 \mu \mathrm{M} 2,4-\mathrm{D}+18.59 \mu \mathrm{M} \mathrm{KIN}$ & $43.74^{\mathrm{f}} \pm 2.55$ & $10.00^{\mathrm{e}} \pm 0.71$ \\
\hline 10 & M10 & $\mathrm{MS}+0.2 \mu \mathrm{M} \mathrm{IAA}+4.5 \mu \mathrm{M} \mathrm{BAP}$ & $67.27^{d} \pm 2.85$ & $12.75^{\mathrm{d}} \pm 0.85$ \\
\hline 11 & M11 & $\mathrm{MS}+1.14 \mu \mathrm{M} \mathrm{IAA}+19.97 \mu \mathrm{M}$ BAP & $97.95^{\mathrm{a}} \pm 1.19$ & $27.25^{\mathrm{a}} \pm 0.48$ \\
\hline 12 & M12 & $\mathrm{B} 5+4.44 \mu \mathrm{M}$ BAP & $40.34^{\mathrm{f}} \pm 0.91$ & $11.25^{\mathrm{de}} \pm 0.48$ \\
\hline 13 & M13 & $\mathrm{B} 5+8.88 \mu \mathrm{M} \mathrm{BAP}$ & $62.40^{\mathrm{e}} \pm 1.08$ & $15.25^{\mathrm{c}} \pm 0.85$ \\
\hline 14 & M14 & $\mathrm{B} 5+1.14 \mu \mathrm{M} \mathrm{IAA}+19.97 \mu \mathrm{M}$ BAP & $95.71^{\mathrm{ab}} \pm 0.22$ & $25.50^{\mathrm{a}} \pm 0.64$ \\
\hline 15 & M15 & $\begin{array}{c}\mathrm{MS}+4.65 \mu \mathrm{M} \mathrm{KIN}+6.65 \mu \mathrm{M} \mathrm{BAP}+10 \mathrm{mg} \\
\text { Bavistin }\end{array}$ & $73.16^{c} \pm 2.30$ & $18.25^{\mathrm{b}} \pm 0.63$ \\
\hline \multirow[t]{5}{*}{16} & M16 & Modified MS2* $+1.14 \mu \mathrm{M} \mathrm{IAA}+19.97 \mu \mathrm{M}$ BAP & $82.54 \pm 0.91$ & $21.00 \pm 0.91$ \\
\hline & & Mean & 64.26 & 16.02 \\
\hline & & SE(m) & 1.51 & 0.67 \\
\hline & & CD & 4.29 & 1.91 \\
\hline & & $\mathbf{C V}$ & 4.68 & 8.35 \\
\hline
\end{tabular}

Each medium was supplemented with $3 \%$ sucrose as carbon source and solidified with $0.8 \%$ agar. *Modified $\mathrm{MS} 2\left(\right.$ without $\mathrm{NH}_{4} \cdot \mathrm{NO}_{3}, \mathrm{KNO}_{3}-$ $2020 \mathrm{mg} / \mathrm{l}$, and decreased concentration of $\mathrm{CaCl}_{2} \cdot 2 \mathrm{H}_{2} \mathrm{O}-220.50 \mathrm{mg} / \mathrm{l}, \mathrm{KH}_{2} \cdot \mathrm{PO}_{4}-44 \mathrm{mg} / \mathrm{l}$ and $\mathrm{H}_{3} \mathrm{BO}_{3}-1.25 \mathrm{mg} / \mathrm{l}$ ).

Values expressed as mean $\pm \mathrm{SE}$. Mean value $(\mathrm{n}=4)$ in columns bearing same letter are not significantly different using Duncan's Multiple Range Test at $5 \%$ level.

Figure.1 A: The cultured shoot apex; B: Differentiated shoots on medium M $11(\mathrm{MS}+1.14 \mu \mathrm{M}$ IAA + $19.97 \mu \mathrm{M}$ BAP); C: Multiplication of shoots after subculture on medium M 11; D: Rhizogenesis from in vitro developed shoot on medium MS + 4.92 $\mu \mathrm{M}$ IBA; E: Acclimatization of plantlets and F: Pot transfer of acclimatized plant.
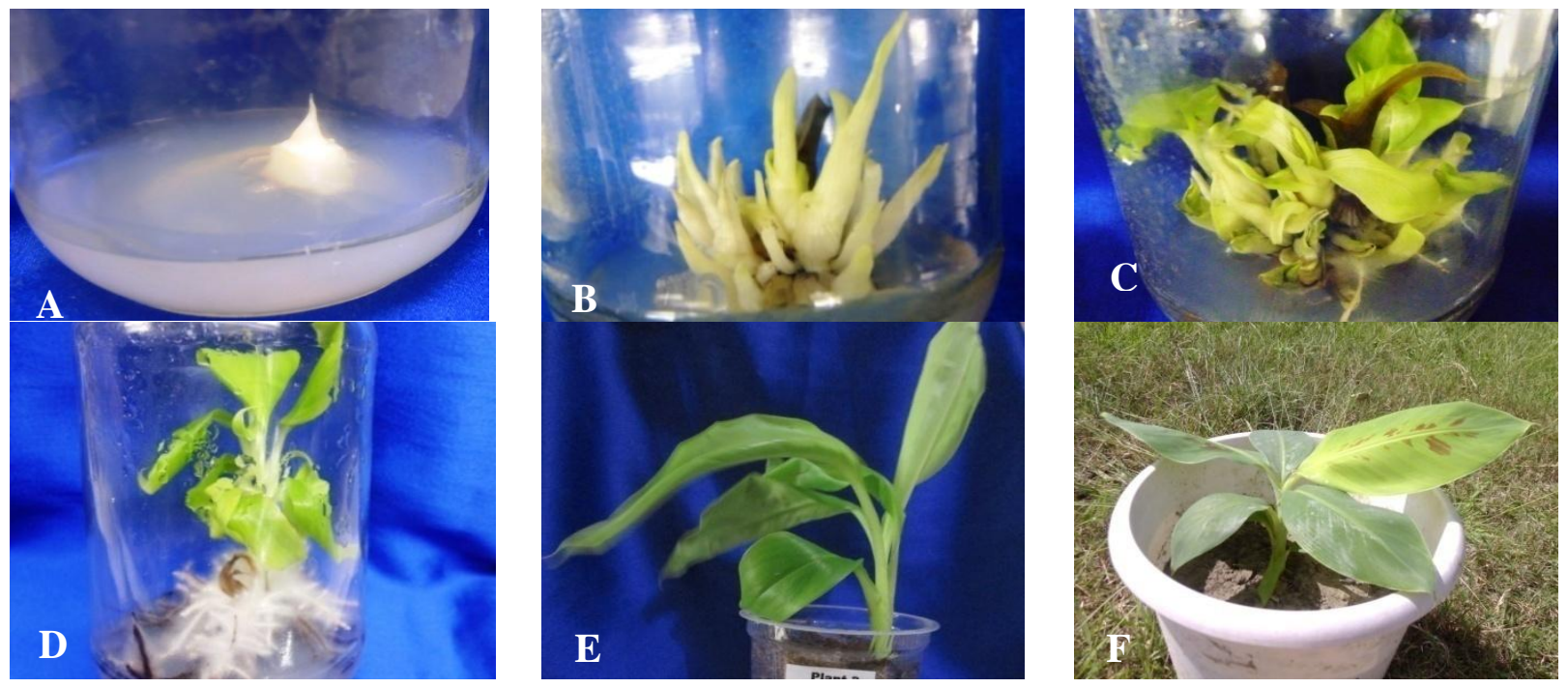
Table.2 The effect of subculture cycle on number of shoot differentiation per culture

\begin{tabular}{|c|c|c|c|}
\hline S. No. & Media & $\begin{array}{c}\text { Number of multiple } \\
\text { shoots/subculture }\end{array}$ & $\begin{array}{c}\text { Percentage change in } \\
\text { number of multiple } \\
\text { shoots/subculture }\end{array}$ \\
\hline 1 & Sub1 & $28.50^{\mathrm{a}} \pm 0.64$ & 0 \\
\hline 2 & Sub2 & $28.75^{\mathrm{a}} \pm 0.48$ & +0.88 \\
\hline 3 & Sub3 & $27.25^{\mathrm{a}} \pm 0.48$ & -4.39 \\
\hline 4 & Sub4 & $26.75^{\mathrm{b}} \pm 0.48$ & -6.14 \\
\hline 5 & Sub5 & $26.75^{\mathrm{b}} \pm 0.63$ & -6.14 \\
\hline 6 & Sub6 & $23.75 \pm 0.85$ & -16.67 \\
\hline 7 & Sub7 & $20.50 \pm 0.64$ & -28.07 \\
\hline 8 & Sub8 & $17.00 \pm 0.71$ & -40.35 \\
\hline & Mean & 24.91 & \\
\hline & SE(m) & 0.63 & \\
\hline & CD & 1.84 & \\
\hline
\end{tabular}

Values expressed as mean \pm SE. Mean value $(n=4)$ in columns bearing same letter are not significantly different using Duncan's Multiple Range Test at $5 \%$ level.

Cytokinin codes for the repressor protein AUX/IAA, which in turn inhibits the biosynthesis of auxin in cells (Dello Ioio et al., 2008). An optimal concentration of plant growth hormone cytokinin in medium helps in cell division and multiplication. Supplementation of auxin in low concentration exogenously in medium with high concentration of cytokinin helps plant (explants or shoot apices) to maintain a level of the hormone which is necessary for the maintenance of undifferentiated SAM descendents in cell. These hormonal signals lend a hand to distinct genes and gene combinations as SCARECROW (SCR) and SHORT-ROOT (SHR) to specify root and shoot meristem formation (Gilbert, 2010), which in turn enhances the shoot differentiation.

The media M11 and M14 which resulted in the highest frequency and number of differentiated shoots per culture had lower auxin and higher cytokinin concentrations. Similar results of the maximum shoot differentiation from the cultured shoot apices of different cultivars of banana on media with similar proportion of auxin and cytokinin was observed by Iqbal, et al., (2013) and Ahmed, et al., (2014). However, Iqbal et al., (2013) utilized the medium MS $+22.2 \mu \mathrm{M}$ BAP and $8.56 \mu \mathrm{M}$ IAA with higher concentrations of same auxin and cytokinin along with 10\% coconut water for shoot multiplication from shoot tip culture of cv. Williams. Ahmed, et al., (2014) used medium (MS $+17.75 \mu \mathrm{M}$ $\mathrm{BAP}+11.42 \mu \mathrm{M}$ IAA) with low concentration of BAP but higher concentration of IAA compared to present work for development of adventitious shoots from shoot tip culture of cv. Grand Naine. Both the workers worked on autotriploid (AAA) cultivars of banana like cv. Robusta of present study. Choudhary, et al., (2014) reported the maximum 15.6 numbers of shoots per culture on MS medium with 2.0 $\mathrm{mg} / 1 \mathrm{BAP}$ and $0.5 \mathrm{mg} / 1 \mathrm{NAA}$, and 9.7 per culture on MS medium supplemented with 30 $\mathrm{mg} / \mathrm{l}$ adenine sulphate, $2 \mathrm{mg} / \mathrm{l} \mathrm{BAP}$ and 0.5 mg/l NAA from the same cv. Robusta. The next best medium for multiple shoot differentiation was M4 (MS + $22.19 \mu \mathrm{M}$ BAP). Similarly, Arinaitwe, et al., (2000) got the best shoot proliferation on higher 
concentration of only BAP $(28.8 \mu \mathrm{M})$. They showed that BAP was the best cytokinin for shoot proliferation but the shoot proliferation rate of 3.5 and 8.0 per culture in two cultivars Kibuzi and Bwara respectively with same genome as of cv. Robusta was much less than observed in the present work.

The impact of media M6 (MS $+4.54 \mu \mathrm{M}$ TDZ) and M7 (MS + $9.08 \mu \mathrm{M}$ TDZ) on induction of shoot multiplication were at par. TDZ is a diphenyl urea derived $N$-phenyl- $N$ '1,2,3-thiadiazol-5-ylurea resistant to all cytokinin oxidases and induces the accumulation of endogenous cytokinins (Kaminek, 1992). Arinaitwe, et al., (2000) studied the effect of TDZ for the first time on proliferation rate in Musa spp. They observed that the proliferation rates of cvs. Bwara and Kibuzi increased with increasing concentrations of TDZ $(0.045 \mu \mathrm{M}$ to1.14 $\mu \mathrm{M})$ in media and afterwards decreased with increased concentrations of TDZ $(6.81 \mu \mathrm{M})$ as found in the present work. Lee (2005) also reported that lower concentration of TDZ ( 0.2 $\mathrm{mg} / \mathrm{l})$ was more effective than higher concentrations. Similar result of multiple shoot formation response on TDZ was reported by Kumari and Kumar (2016).

The scope of an efficient micropropagation system is to achieve a very high propagule multiplication rate. The shoot apices culture of banana cultivar Robusta resulted in establishment of high rate of multiplication of shoots on medium M11. The frequency of multiple shoot differentiation was not affected generally, but the number of differentiated multiple shoots per subcultured in vitro developed shoots varied with the increasing culture cycles. The mean number of differentiated shoots per culture remained more or less the same upto $5^{\text {th }}$ subculture cycle and thereafter encumbered with further subcultures. Similar observation of subculturing effect on the proliferation rate of shoot tip culture of banana was reported by
Kumar, et al., (2005) and Kumari and Kumar (2016). Contrary to present work Kumar, et al., (2005) got higher number of differentiated shoots in $3^{\text {rd }}$ to $5^{\text {th }}$ subcultures.

The stressful environment of plant tissue culture imposed induction and accumulation of variation in cultured plant tissues. Multiple in vitro tissue culture factors induced variations in plant phenotype, gene expression and genotypic features. The observed decline in multiple shoot differentiation efficiency of subcultured in vitro developed shoots after $5^{\text {th }}$ subculture might be due to the accumulation of variations resulting from somaclonal variations which prevented regeneration of shoots from variant cells. Similarly, contribution of subculturing onto multiplication ability of in vitro developed shoot buds were recognized by Us-Camas, et al., (2014) and Saraswathi, et al., (2014). Aremu, et al., (2013) also reported significant effect of subculturing onto proliferation and multiplication potential of banana cv. 'Williams' after $6^{\text {th }}$ subculture as found in present investigation. Many investigators reported the impact of subculture cycles on the efficiency of differentiation of multiple shoots was influenced by the genotype of the banana cultivars (Abdullah et al., 1997; Rodrigues et al., 1998).

Development of roots or rhizogenesis is an important organogenesis without which in vitro developed shoots may not be converted in to plants and transplanted to ex vitro conditions. The in vitro multiplicated plant propagaules were divided into single shoots and inoculated onto root inducing medium consisting of $4.92 \mu \mathrm{M}$ IBA. Auxin induces vascular differentiation and plays an important role in induction and development of roots (North et al., 2012; Ngomuo et al., 2014). Indole-3-butyric acid (IBA), a persuasive plant auxin, was also observed to produce the greatest number of roots in present experiment. Similarly, Rahman, et al., 
(2013) and Saraswathi, et al., (2014) reported its effectiveness in development of roots in banana cultivars. Manchanda, et al., (2012) and Kumari and Kumar (2016) obtained profuse rooting from the base of cultured shoot of banana cultivars utilizing similar concentration of IBA $(1.0 \mathrm{mg} / \mathrm{l})$. Strosses, et al., (2004) also subcultured in vitro developed shoots on the same medium for rhizogenesis and got cent-percent response during regeneration of banana plantlets.

The well rooted tissue culture plantlets of cv. Robusta consisting of healthy shoot were acclimatized progressively to ex vitro environmental conditions resulted in successful establishment of these plants at fields. Thus, the work resulted in accomplishment of more efficient and robust micropropagation system with a high multiplication rate for the valuable $\mathrm{cv}$. Robusta as compared to earlier results (Senthilkumar and Ramsundar, 2009; Choudhary et al., 2014).

\section{References}

Abdullah, K., Khan, IA., Siddiqui, SH., Ahmed, M. and Siddiqui, KA. 1997. In vitro culture of indigenous and exotic banana clones for maximum multiplication. Pakistan Journal of Botany. 29: 143-50.

Ahmed, S., Sharma, A., Singh, AK., Wall, VK. and Kumari, P. 2014. In vitro multiplication of banana (Musa sp.) cv. Grand Naine. African Journal of Biotechnology. 13: 2696-2703.

Aremu, AO., Bairu, MW., Szǚcová, L., Dole zal, K., Finnie, JF. and Van, Staden, J. 2013. Genetic fidelity in tissuecultured 'Williams' bananas - The effect of high concentration of topolins and benzyladenine. Scientia Horticulturae. 161: 324-327.

Arinaitwe, G., Rubaihayo, PR. and Magambo, MJS. 2000. Proliferation rate effects of cytokinins on banana (Musa spp.) cultivars. Scientia Horticulturae. 86: 1321.

Choudhary, D., Kajla, S., Poonia, AK., Duhan, JS., Kumar, A. and Kharb, P. 2014. An efficient micropropagation protocol for Musa paradisiaca cv. Robusta: A commercial cultivar. Annals of Biology. 30: 25-31.

Dello, Ioio, R., Nakamura, K., Moubayidin, L., Perilli, S., Taniguchi, M., Morita, MT., Aoyama, T., Costantino, P. and Sabatini, S. 2008. A genetic framework for the control of cell division and differentiation in the root of meristem. Science. 322: 1380-1384.

Duncan, OD. and Duncan, B. 1955. A methodological analysis of segregation indexs. American Sociological Review. 20: 210-217.

Ghosh, A., Ganapathi, TR., Nath, P. and Bapat, VA. 2009. Establishment of embryogenic cell suspension cultures and Agrobacterium-mediated transformation in an important Cavendish banana cv. Robusta (AAA). Plant Cell Tissue and Organ Culture. 97: 131-139.

Gilbert, SF. 2010 Developmental Biology. $8^{\text {th }}$ edition. Sinauer Associates, Inc MA: Publishers Sunderland. p. 627-653.

Iqbal, MM., Muhammad, A., Hussain, I. and Bilal, H. 2013. Optimization of in vitro micropropagation protocol for banana (Musa Sapientum L.) under different hormonal concentrations and growth media. International Journal of Agricultural Innovation and Research. 2: 23-27.

Jiang, K., Meng, YL. and Feldman, LJ. 2003. Quiescent center formation in maize roots is associated with an auxin regulated oxidizing environment. Development. 130: 1429-1438.

Kaminek, M. 1992. Progress in cytokinin research. Trends in Biotechnology. 10: 159-162.

Kumar, R., Sinha, K. and Kumar S. 2005. Micropropagation of banana cv. Malbhog through meristem tip culture in consort with thermotherapy. Phytomorphology. 
55: 17-22.

Kumari, A. and Kumar, H. 2016. Development of an efficient micropropagation system in banana cv. Malbhog (AAB). Advances in Life Sciences. 5: 3487-3494.

Lee, SW. 2005. Thidiazuron in the improvement of banana micropropagation. Acta Horticulturae. 692: 67-74.

Manchanda, P., Kaur, A. and Gosal, SS. 2012. Micropropagation of banana (Musa acuminata) through proliferation of axillary shoots. Indian Journal of Agricultural Sciences, 82: 451-454.

Ngomuo, M., Mneney, E. and Ndakiademi, PA. 2014. The in vitro propagation techniques for producing banana using shoot tip cultures. American Journal of Plant Sciences. 5: 1614-1622.

North, JJ., Ndakidemi, PA. and Laubscher, CP. 2012. Effects of antioxidants, plant growth regulators and wounding on phenolic compound excretion during micropropagation of Strelitzia reginae. International Journal of Physical Science.7: 638-646.

Rahman, S., Biswas, N., Hassan, MM., Ahmed, MG., Mamun, ANK., Islam, MR., Moniruzzaman, M. and Haque, ME. 2013. Micropropagation of banana (Musa sp.) cv. Agnishwar by in vitro shoot tip culture. International Research Journal of Biotechnology: 4: 83-88.

Rodrigues, PHV., Tulmann, Neto, A., Cassieri, Neto, P. and Mendes, BMJ. 1998. Influence of the number of subcultures on somoclonal variation in micropropagated Nanico (Musa spp. AAA group). Acta Horticulturae. 490: 469-473.

Saraswathi, MS., Praveena, S., Uma, S.,
Thangavelu, R., Kannan, G., Backiyarani, S. and Arivazhagan, T. 2014. Development of an efficient micropropagation technique for Musa cv. Udhayam (AAB). Indian Journal of Horticulture. 71: 452-457.

Senthilkumar, M. and Ramsundar, V. 2009. Micropropagation of banana Musa spp. cv. Robusta (AAA). Plant Cell Biotechnology and Molecular Biology. 10: 1-16.

Simmonds, NW. 1982. Bananas. $2^{\text {nd }}$ edition. London and New York: Longman. p. 512.

Skoog, F. and Miller, CO. 1957. Chemical regulation of growth and organ formation in plant tissues cultured in vitro. Symposium of Social Experimental Biology. 11: 118-131.

Strosse, H., Houwe, I. and Panis, B. 2004. Banana cell and tissue culture review. Banana improvement cellular molecular biology and induced mutations. Proceedings of meeting held in Leuven Belgium, Belgium, pp. 1-12.

Taiz, L. and Zeiger, E. 2010. Plant Physiology. $5^{\text {th }}$ edition. Sinauer Associates Inc, U.S.A: Publishers Sunderland, Massachusett. p. 560-562.

Us-Camas, R., Rivera-Solı's, G., Duarte-Ake, F. and De-la-Peña, C. 2014. In vitro culture: an epigenetic challenge for plants. Plant Cell Tissue and Organ Culture. 118: 187-201.

Vani, AKS. and Reddy, GM. 1999. Novel technique in efficient micropropagation of certain popular banana cultivars. Journal of Genetics and Plant Breeding. 53: 247-250.

\section{How to cite this article:}

Anita Kumari and Harsh Kumar. 2018. High in vitro Shoot Multiplication for Efficient Micropropagation of Banana Cv. Robusta (AAA). Int.J.Curr.Microbiol.App.Sci. 7(07): 33193326. doi: https://doi.org/10.20546/ijcmas.2018.707.386 